\title{
Commentary
}

\section{Deliveroo and Riders' Strikes: Discriminations in the Age of Algorithms}

\author{
By Vincenzo Pietrogiovanni, Associate Professor, Lund University, Sweden and \\ Aarhus University, Denmark
}

The impact of artificial intelligence (AI) and digitalization on work and its regulation is a continuous source of legal challenges for scholars and practitioners. A recent order by the Court of Bologna ${ }^{1}$ opens a new and fascinating dimension in the legal and judicial affair of "riders" and on-demand work through digital platforms managed by multinational companies. The case, unlike many previous ones, does not deal with classification but instead with discrimination and algorithmic management, which can be a more complicated issue.

In December 2019, three local federations affiliated with the main Italian trade union, the Italian General Confederation of Labour (CGIL), filed a complaint based on Article 5.2 of Legislative Decree no. 216 of 2003 - the implementation act of the Council Directive 2000/78/EC establishing a general framework for equal treatment in employment and occupation-before the Court of Bologna against the company Deliveroo Italia srl. The main issue of the dispute was the possible discrimination resulting from Deliveroo's algorithm used at the time for the distribution and management of work flows among those riders who had made themselves available in advance by booking

1 Maria Vittoria Ballestrero, "Ancora sui rider. La cecità discriminatoria della piattaforma," Labor, 19 January 2021; Adalberto Perulli, "La discriminazione algoritmica: brevi note introduttive a margine dell'ordinanza del Tribunale di Bologna," Lavoro Diritti Europa, January 2021; Antonio Baylos, "El algoritmo no es neutral. No permite ejercer derechos fundamentales a los trabajadores de plataformas," Según Antonio Baylos (blog), January 2021, https://baylos. blogspot.com/2021/o1/el-algoritmo-no-es-neutral-no-permite.html. 
work sessions - known as slots. The plaintiffs asked the Court to ascertain and declare the discrimination regarding the conditions of access and, in particular, of the processing parameters of the ranking system that affect priority of choice in work sessions without considering the cause that gave rise to the noncompliance with the session booked. The core legal aspect of this case is the possibility of an algorithm to discriminate, namely, on grounds of beliefs (as in the sense of participating to a collective action) or disability. This ruling is of interest not only for the Italian jurisdiction but also internationally because it is the first in Europe (if not the world) concerning algorithmic discrimination.The Court first decided on two preliminary issues: one regarding Deliveroo's request to end the dispute because the algorithm was no longer in use; the second concerning the application of antidiscrimination legislation invoked by the trade unions to riders (who are not contractually employees). ${ }^{2}$ The Court then passed on the main concern, concluding indirect discrimination in access to the digital booking of work sessions, conditions based on statistics relating to the "participation and reliability" of workers. It sentenced the defendant to remove the effects of its conduct and to pay compensation to the plaintiffs for nonpecuniary damage in the amount of 50,000 euros as well as for reimbursement of litigation costs. ${ }^{3}$

For the first time, a judge was asked to try to access the "black box" 4 and ascertain whether algorithms - the main driving force of AI at work-can constitute discriminatory behavior on behalf (rectius: on the shoulders) of the company that uses them. In particular, the unions alleged collective discrimination in corporate conduct on the basis of algorithmic management of trade union activity. ${ }^{5}$ The Italian legal system specifically protects discrimination for reasons related to freedom and trade union activity (Article 15 and Article 28 of the Workers' Statute). In this case, however, trade unions decided to resort antidiscrimination legislation. It is crucial in this regard to connect the protected ground of belief or personal convictions, as referred to in Legislative

2 For more, see Silvia Borelli and Mura Ranieri, "La discriminazione nel lavoro autonomo. Riflessioni a partire dall'algoritmo Frank," Labour \& Law Issues 7, no. 1 (2021): I.18-I.47, https:// doi.org/10.6og2/issn.2421-2695/13169.

3 Tribunal of Bologna, Order no. 2949/2019, 31 December 2020.

4 Frank Pasquale, The Black Box Society. The Secret Algorithms That Control Money and Information (Cambridge, MA: Harvard University Press, 2015).

5 The Bologna Court could rely on the authoritative precedent of ruling no. 1/2020 of the Supreme Court, according to which "within the general category of personal beliefs characterized by the heterogeneity of the hypotheses of ideological discrimination extended to the sphere of social relations, ... discrimination for trade union reasons with the consequent prohibition of acts can also be included or conduct suitable for achieving a diversity of treatment or prejudice due to the affiliation or participation of the worker in trade union activities" (§ 9.6). 
Decree no. 216/2003, with the trade union activity. This choice is neither odd nor unusual. On the contrary, it is meant to take advantage both of the extension of the antidiscrimination protection beyond subordinate work and of the burden of proof regime.

This case law builds on a clear distinction between Article 21 of the Charter of Fundamental Right of the EU ${ }^{6}$ and Article 19 Treaty on the Functioning of the $\mathrm{EU}^{7}$ and, in Directive 2000/78, between religious and personal convictions. All these provisions do not mention expressly discrimination for trade union reasons but this result can be achieved by interpretating the Charter in light of the European Convention of Human Rights (Article 11) and the European Court of Human Rights' case law. ${ }^{8}$

\section{How an Algorithm Can Discriminate}

The self-service booking system is based on a score attributed to each rider and processed on two parameters, reliability and participation. Each rider is periodically profiled by statistics that assess the compliance rate of the previous fourteen days of work sessions and not canceled within the regulation twenty-four hours. Once a work session related to a specific delivery area has been booked, if the rider does not cancel the booking in those twenty-four hours prior, they are obliged to go within the perimeter of the work area booked in order to log in within a maximum time frame of fifteen minutes, because otherwise failure to connect within this term results in a loss of score, which might result in a penalty for the rider in their statistics. Indeed, the weekly booking system allows riders with the highest score to book with priority the best slots,

6 Article 21 CFREU reads as follows: "Article 21 - Non-discrimination

1. Any discrimination based on any ground such as sex, race, colour, ethnic or social origin, genetic features, language, religion or belief, political or any other opinion, membership of a national minority, property, birth, disability, age or sexual orientation shall be prohibited.

2. Within the scope of application of the Treaties and without prejudice to any of their specific provisions, any discrimination on grounds of nationality shall be prohibited."

7 Article 19.1 TFEU reads as follows: "Article 19 (ex Article 13 TEC)

1. Without prejudice to the other provisions of the Treaties and within the limits of the powers conferred by them upon the Union, the Council, acting unanimously in accordance with a special legislative procedure and after obtaining the consent of the European Parliament, may take appropriate action to combat discrimination based on sex, racial or ethnic origin, religion or belief, disability, age or sexual orientation."

8 Marzia Barbera and Venera Protopapa, "Il caso Fiat: come la tutela antidiscriminatoria riformula il conflitto sindacale," Rivista Giuridica del Lavoro 2 (2014): 163. 
which are gradually filled and thus unavailable for riders with lower priority, who would eventually get fewer and fewer job opportunities over the time.

The discrimination happens when riders cannot log in by going to the delivery area during their slots because they are participating in a strike (or for any other legitimate absence such as illness or needs related to a minor child or person with disability), adversely affecting their access to work. In this way, the Bologna Court has ascertained that the algorithm that manages this process might create unreasonable restrictions on workers willing or needing to exercise their fundamental rights.

The unequal treatment is the indifference or blindness of the platform in regard to why workers did not promptly cancel their reserved slots. According to the Court, "to treat in the same way those who do not participate in a booked session for futile reasons and those who do not participate because they are on strike (or because they are sick, have a disability, or assist a disabled person or a sick minor, etc.) in practice discriminates the latter, possibly marginalizing him from the priority group and thus significantly reducing his future opportunities for access to work." 9

In addition, the algorithm's blindness is not a misfortune or mistake because the system considers two circumstances (an accident on consecutive shifts and a system malfunction) worthy of protection. This led the Court to affirm that "the platform can remove the blindfold that makes it 'blind' or 'unconscious' with respect to the reasons for the rider's failure to work and, if it does not, because it has deliberately chosen to put all the reasons-regardless of whether or not they are protected by the legal system."10

\section{If an Algorithm Can Directly or Indirectly Discriminate}

This case is more than likely just the first in a series of rulings on algorithmic discrimination. ${ }^{11}$ However, there is no reason-at least, so far- to think that discrimination by algorithms need either different principles or rules than those already written into European national and supranational legislation or alternative interpretations of those principles and rules. On this point, the Court of Bologna interpreted the discrimination as indirect rather than direct discrimination.

9 Tribunal of Bologna, Order no. 2949/2019, 19.

10 Ibid., 20.

11 Raphaële Xenidis, "Turning EU equality law to algorithmic discrimination: Three pathways to resilience," Maastricht Law Journal of European and Comparative Law 27 (2020): 736. 
In general, the debate on categorizing algorithmic discrimination as direct or indirect discrimination is ongoing. Because of the black box nature of many algorithms, some suggest that "tracking differential treatment based on protected grounds might prove impossible, making it very difficult to prove a case of direct discrimination" and that therefore the indirect discrimination could be more workable. ${ }^{12}$ Others suggest instead that, even though transparency of machines is often impossible, the EU Court of Justice has shown in the Chez case $^{13}$ that direct discrimination on the basis of stereotypes and prejudices "do[es] not necessarily require the ascertainment of a conscious discriminatory intent, precisely due to the unconscious nature of both."14

Additional attention on scholarship and case law on this point is merited.

12 Janneke Gerards and Raphaële Xenidis, "Algorithmic Discrimination in Europe: Challenges and Opportunities for EU Equality law," European Futures, 3 December 2020, https:// www.europeanfutures.ed.ac.uk/algorithmic-discrimination-in-europe-challenges-andopportunities-for-eu-equality-law.

13 CJEU, CHEZ Razpredelenie Bulgaria AD v Komisia za zashtita ot diskriminatsia, Case C-83/14, 16 July 2015, ECLI:EU:C:2015:480.

14 Marzia Barbera, "Discriminazioni algoritmiche e forme di discriminazione," Labour \& Law Issues 7, no. 1 (2021): 14, https://doi.org/10.6o92/issn.2421-2695/13127. 